\title{
Kamu Üniversitelerinde İç Kontrol ve Kalite Uygulamaları: Mehmet Akif Ersoy Üniversitesi Örneği
}

\author{
Adnan KALKAN ${ }^{1 *}$, Mehmet TEPELI ${ }^{2}$ \\ ${ }^{1}$ Doç. Dr., Burdur Mehmet Akif Ersoy Üniversitesi, İşletme Fakültesi, orcid id: 0000-0002-2270-4100 \\ ${ }^{2}$ Burdur Mehmet Akif Ersoy Üniversitesi, Sosyal Bilimler Enstitüsü, orcid id: 0000-0001-6054-9562
}

Geliş Tarihi/Received: 26.03.2018

Kabul Tarihi/Accepted: 18.07.2018

Araştırma Makalesi/Research Article

\section{ÖZET}

Üniversiteler bilimsel özerkliğe ve kamu tüzel kişiliğine sahip yüksek düzeyde eğitimöğretim, bilimsel araştırma-geliştirme, yayın ve danışmanlık yapmak üzere kurulan yükseköğretim kurumlarıdır. Üniversitelerde denetim faaliyetlerinin gerçekleşmesi ile kalite uygulamalarının yerleşmesi ve yaygınlaştırılması çalışmalarını yürütmek amacıyla 23 Temmuz 2015 tarih ve 29423 sayılı Resmi Gazetede yayımlanarak yürürlüğe giren Yükseköğretim Kalite Güvencesi Yönetmeliği kapsamında Yükseköğretim Kurulundan bağımsız olarak Yükseköğretim Kalite Kurulu oluşturulmuştur. Bu yönetmeliğe dayanılarak "Yükseköğretim Kalite Kurulunun Çalışma Usul ve Esasları" belirlenmiştir. Bu mevzuat çerçevesinde Mehmet Akif Ersoy Üniversitesi Kalite Güvence çalışmalarını 2016 yılından itibaren başlatmış ve o günden bugüne kadar kurum iç değerlendirme raporlarını oluşturmaktadır. $\mathrm{Bu}$ çalışmanın amacı Mehmet Akif Ersoy Üniversitesinde Bölgesel Kalkınma Odaklı Misyon Farklılaşması ve Tarım ve Hayvancılık Alanında İhtisaslaşma Programı ile bütünleşik olarak yürütülen Kalite Güvence Sistemi uygulamaları irdelenmeye çalışıllmıştır.

Anahtar kelimeler: İç Kontrol, Kalite Güvence Sistemi, Kurum İç Değerlendirme, Kurumsal Dış Değerlendirme, Üniversite.

* Sorumlu yazar/Corresponding author

E-mail/e-ileti: adnankalkan@mehmetakif.edu.tr 


\title{
Internal Audit and Quality Practices in Public Universities: A Case Study of Mehmet Akif Ersoy University
}

\begin{abstract}
Universities are institutions of higher education established to carry out high-level educationtraining, scientific research \& development, publication and counseling, with scientific autonomy and public legal entity. The Higher Education Quality Board has been established independently from the Higher Education Council within the scope of the Higher Education Quality Assurance Regulation, which was enacted by publishing the Official Gazette dated July 23, 2015 and numbered 29423 with the aim of realizing audit activities at universities and carrying out studies for the settlement and dissemination of quality applications. Based on this regulation, "Working Procedures and Principles of Higher Education Quality Board" has been determined. Within the framework of this legislation, Mehmet Akif Ersoy University has started Quality Assurance studies since 2016 and has created internal evaluation reports so far. The purpose of this paper was to examine the applications of the Quality Assurance System, which is carried out in Mehmet Akif Ersoy University integrated with the Regional Development Focused Mission Discrimination and Specialization Program in Agriculture and Livestock Field.
\end{abstract}

Keywords: Internal Audit, Quality Assurance System, Internal Evaluation of Institution, Institutional External Evaluation, University.

\section{GÍRİŞ}

Üniversiteler yasal mevzuatlar gereği 2547 sayılı Yükseköğretim Kanunu ve 124 sayılı Yükseköğretim Üst Kuruluşları ile Yükseköğretim Kurumlarının İdari Teşkilatı Hakkında Kanun Hükmünde Kararname hükümleri çerçevesinde kurulurlar. Üniversitelerin teşkilatlanma politikası ile denetimi kuruluş mevzuatları gereği Yükseköğretim Kurulu tarafından yapılmaktadır. Bu çerçevede üniversitelerde denetim faaliyetlerinin gerçekleşmesi ile kalite uygulamalarının yerleşmesi ve yaygınlaştırılması çalışmalarını yürütmek amacıyla Yükseköğretim Kurulu bünyesinde Yükseköğretim Kalite Kurulu oluşturulmuştur.

Üniversiteler bilimsel özerkliğe ve kamu tüzel kişiliğine sahip olarak yüksek düzeyde eğitim-öğretim, bilimsel araştırma, yayın ve danışmanlık yapmak üzere kurulan yükseköğretim kurumlarıdır. Bu amaçla Mehmet Akif Ersoy Üniversitesi 17 Mart 2006 tarih ve 26111 sayılı resmi gazetede yayınlanan 5467 sayılı kanunla kurulmuş ve 2017 yılı 
itibariyle hızlı bir ilerleme kaydederek kendisi ile birlikte kurulan üniversiteler içerisinde ilk sıralarda yerini almıştır. Yine Üniversitemiz, Bölgesel Kalkınma Odaklı Misyon Farklılaşması ve İhtisaslaşması Programı Tarım ve Hayvancılık Alanında öncelikli üniversite olarak faaliyetlerini sürdürmektedir.

Yükseköğretim Kurulu bünyesinde 23 Temmuz 2015 tarih ve 29423 sayılı Resmi Gazetede yayımlanarak yürürlüğe giren Yükseköğretim Kalite Güvencesi Yönetmeliği kapsamında Yükseköğretim Kalite Kurulu oluşturulmuş ve üye sayısı 13 olarak belirlenmiştir. $\mathrm{Bu}$ yönetmeliğe dayanılarak "Yükseköğretim Kalite Kurulunun Çalışma Usul ve Esasları" belirlenmiştir. Bu usul ve esaslar kapsamında, Yükseköğretim Kalite Kurulu üniversitelerde kalite politikasının oluşturulması ve yaygınlaştırılması, akredistasyon, iç ve dış değerlendirme süreçlerinin gerçekleştirilmesi faaliyetlerini yürütmektedir.

Kamu yönetimi ile kamu mali yönetiminde yaşanan gelişmeler dikkate alınarak yapılan reformlar 1şı̆̆ında üniversitelerde İç Kontrol Sistemi ile Kalite Uygulamalarının gerçekleşmesi ve yaygınlaşması amacıyla çıkarılan yasal mevzuatlar aşağıda belirtilmiştir:

5018 sayılı Kamu Mali Yönetimi ve Kontrol Kanunu

> İç Kontrol ve Ön Mali Kontrole İlişkin Usul ve Esaslar

$>$ Kamu İç Kontrol Standartları Tebliği

$>$ Kamu İç Kontrol Rehberi

> Kamu İç Kontrol Standartlarına Uyum Eylem Planı Rehberi

> Yükseköğretim Kalite Güvencesi Yönetmeliği

$>$ Strateji Geliştirme Birimlerinin Çalışma Usul ve Esasları Hakkında Yönetmelik

$>$ Kurumsal Diş Değerlendirme Yönergesi

> Kamu İdareleri İçin Stratejik Planlama Kılavuzu

> Üniversiteler İçin Stratejik Plan Hazırlama Rehberi

Üniversitelerde kalite çalışmaları, iç denetim ve dış denetime ilişkin süreçler aşağıdaki başlıklar altında anlatılmıştır.

\section{2. İÇ KONTROL SISTEMININ OLUŞTURULMASI}

İç kontrol sistemi, kurumun yasal mevzuatlar çerçevesinde ve belirlenmiş politikalarına uygun olarak faaliyetlerinin etkili, ekonomik ve verimli bir şekilde yürütülmesini, iş ve işlemler ile kayıtlarının doğru ve eksiksiz bir şekilde kaydedilmesini, 
kaynaklarının korunmasını, mali ve yönetim bilgisinin zaman kaybı olmaksızın güvenilir olarak üretilmesini sağlamak üzere kuruluş tarafından oluşturulan etkinlik, yöntem, süreç ve denetimini kapsayan mali ve mali olmayan kontroller bütünüdür (Arslan, 2012:128-129).

Ülkemiz kamu kurumlarında kamu mali yönetiminin saydamlığı ve hesap verilebilirliğini arttırmak, kuruluşlarda etkin bir iç kontrol sisteminin oluşturulması amacıyla Kamu İç Kontrol Rehberi yayımlanmıştır. Bu rehber ile COSO küpü örnek alınarak, iç kontrol bileşenleri ve standartları belirlenmiş, iç kontrol sisteminin işleyiş̧i ve sistemdeki kullanıcıların rol ve sorumlulukları belirlenmiş, iç kontrol süreçlerine ilişkin standartlar tanımlanmış ve böylece kamu idarelerine örnek teşkil etmesi sağlanmıştır.

Kamu İç Kontrol Rehberinde iç kontrol bileşenleri aşağıdaki gibi belirlenmiş ve tanımlanmıştır:

a. Kontrol Ortamı: Kuruluşun iç kontrol uygulamalarını kabullendiği ve iç kontrolün temelinin oluşturulduğu bileşendir. Kamu kurumlarında iç kontrol uygulamalarının gerçekleştirilebilmesi için makul düzeyde kontrol ortamına ihtiyaç duyulmaktadır.

b. Risk Değerlendirme: Bu standart, kamu kurumundaki riskin tespit edilmesini, değerlendirilmesini ve önlemler alınmasını, önlemlerin performansının ölçülmesini ve raporlanmasını kapsamaktadır.

c. Kontrol Faaliyetleri: Bu standart kamu kurumlarında mali ve mali niteliği olmayan faaliyetleri kapsamak ile birlikte tespit edilen risklerin etki/olasılığını azaltıcı önlemleri kontrol etmeyi amaçlayan eylemleri içermektedir.

d. Bilgi ve İletişim: Kamu kurumlarının amaç ve hedefleri doğrultusunda yürüttüğü faaliyetler ile iç kontrol süreçlerinin uygulanması sırasında bilgi verme, raporlama, kayıt ve dosyalama, kanuna uygun olmayan işlemlerin bildirilmesi vb. eylemlerin kamuoyuna veya muhataplarına aktarılmasını sağlayan süreçleri belirleyen standarttır.

e. İzleme: İç kontrol sisteminin kalitesini değerlendirmek amacıyla kamu kurumu genelindeki tüm faaliyetler için gerçekleştirilen değerlendirme süreçlerine yardımcı olacak eylemlerdir.

Mehmet Akif Ersoy Üniversitesi belirlediği amaç ve hedeflerine ulaşmada mevcut yasa ve mevzuatlara uygun olarak faaliyetlerini sürdürmek, iç kontrol uygulamalarını tüm birimlerinde yaygınlaştırmak ve bunu kurum kültürü haline getirmek amaciyla iç kontrol 
süreçlerini uygulamaya koymuştur. $\mathrm{Bu}$ amaçla kendisine pilot birimler belirlemiştir. Pilot birimler üzerinde öncelikle mevcut durum analizi yapılarak birimin misyon, vizyon ve hedeflerine ulaşmada hangi yöntemleri izlediği tespit edilmiştir. Daha sonra bu yöntemleri kullanarak hangi faaliyetleri gerçekleştirdiği belirlenmiş ve iş tanım formları oluşturulmuştur. İş tanım formlarında işin adı, yasal süre, işin sorumlusu ve kim tarafından yerine getirildiği, kullanılan sistemler vb. bilgilere yer verilmiştir. İş tanım formu ile tanımlanan her işin iş analizleri yapılarak işin hangi aşamaları kapsadığı ve nasıl yapıldığı, sürece ilişkin girdi ve çıktılar, sürecin akış diyagramı, izleme ve ölçme kriterleri, vb. tanımlanmıştır. Daha sonra yine iş tanım formları dikkate alınarak görev tanım formları oluşturulmuştur. Görev tanım formları ile birimlerdeki personele ait roller belirlenmiştir. Görev tanım formunda bu rollerin amacı, role sahip olabilmek için gerekli nitelikler ve şartlar, temel iş ve sorumluluklar, yetki düzeyleri vb. tanımlanmıştır.

İç kontrol bileşenlerinden risk değerlendirme sürecini gerçekleştirmek amaciyla tanımlanan işler ana faaliyet bazında belirlenmiştir. Tanımlanan tüm işler kalite komisyonu tarafından gözden geçirilmiş ve birbirine yakın veya birbiri ile ilişkili işler bir araya getirilmiştir. $\mathrm{Bu}$ işlerin tümünü kapsayacak şekilde ana faaliyetin adı oluşturulmuştur. Ana faaliyetlerin her biri için risk analizi yapılmış ve her bir faaliyet için risk düzeyi belirlenmiştir. Risk analizleri, Kamu İç Kontrol Rehberinde yer alan risk yönetim süreci takip edilerek yapılmıştır. Bu kapsamda öncelikle idari, birim ve alt birim düzeyinde riskler belirlenmiş ve risk hiyerarşisi oluşturulmuştur. Daha sonra bu sürecin ilk basamağı olan risklerin tespit edilmesi aşamasına geçilmiş ve faaliyetler üzerinde riskler belirlenmeye çalışılmıştır. $\mathrm{Bu}$ aşamada kurumun hedefleri, paydaşlar ve belirlenen riskin kategorisine de ayrıca dikkat edilmiştir. Stratejik risklerin stratejik plan hazırlanırken belirlenmesi nedeniyle riskler belirlenirken faaliyet düzeyinden stratejik düzeye gidilmiştir. Riskler belirlenirken PESTLE, GZTF/SWOT analizleri ile beyin firtınası yöntemleri kullanılmıştır. Belirlenen risklerin stratejik riskler ile ilişkisi kurulmuştur. Faaliyet üzerinde belirlenen riskler değerlendirilerek etki derecesinin ve gerçekleşme olasılığ hesaplanmıştır. Bu aşamada karşılaşılabilecek olaylar göz önünde bulundurulmalıdır. Risklerin değerlendirilmesi aşaması, tespit edilen risklerin ölçülmesi, riskin önceliklendirilmesi ve kaydedilmesi aşamalarından oluşmaktadır. $\mathrm{Bu}$ noktada ilk iş olarak her riskin etki-olasılık düzeyi ölçülmüş ve bir risk haritası oluşturulmuştur. Risk haritaları, belirlenen risklerin risk seviyelerinin daha rahat görünmesini sağlayarak risk çalışmasının yürütülmesini kolaylaştırmaktadır. Belirlenen riskler önem derecelerine göre önceliklendirilmiş ve önem derecesine göre sıralanarak kaydedilmiştir. 
Belirlenen her risk için bir risk düzeyi tespit edilmiştir. Risk düzeyi tespit edilirken kurumun o risk için katlanacağı seviye temel alınmış ve bu doğrultuda risk düzeyi belirlenmiştir. Risk düzeyi temel alınarak riskin etki ve olasılığını düşürmek ve risk düzeyini indirgemek amacıyla önleyici ve düzeltici faaliyetlerden hangisinin kullanılacağına karar verilmiştir. Belirlenen faaliyetler ışığında tekrar risk analizi yapılarak riskin son etki ve olasılık puanı hesaplanmıştır. Son risk puanı üzerinden riski kabul et, gözlemle vd. faaliyetlerin yürütülmesi kararlaştırılmıştır. Böylece birim üzerinde gerçekleşebilecek tüm riskler ile izleme ve yönlendirme kontrolleri ortaya konulmuştur.

\section{STRATEJIK PLAN PERFORMANS PROGRAMI VE FAALIYYT RAPORU}

Stratejik plan 5018 sayıl Kamu Mali Yönetimi ve Kontrol Kanunu'nda "kamu idarelerinin orta ve uzun vadeli amaçlarını, temel ilke ve politikalarını, hedef ve önceliklerini, performans ölçütlerini, bunlara ulaşmak için izlenecek yöntemler ile kaynak dağılımlarını içeren plan" olarak tanımlanmıştır.

Kamu kurumları için amaç ve hedeflerine ulaşmada faaliyetlerini planlı bir şekilde yürütmek; kaynaklarını etkili, ekonomik ve verimli kullanmak hayati önem arz etmektedir. $\mathrm{Bu}$ amaçla kamuda uygulanan stratejik yönetim modeli ile kamu kurumunun orta ve uzun vadeli planları ile odaklanmak istediği önceliklerini belirlemesine; bütçe hazırlama ve uygulama süreçlerinde kaynaklarını stratejik önceliklere göre tespit etmesine ve dağıtımını sağlamasına; faaliyet ve performans programları ile performans göstergelerini izlemesine ve bu yapıyı sağlayacak bir hesap verme sorumluluğu sisteminin geliştirilmesine temel oluşturulmaktadır.

Kalkınma Bakanlığı tarafından hazırlanan "Kamu İdareleri Iç̧in Stratejik Planlama Kılavuzu” kamu idarelerine stratejik planlama sürecinde yardımcı olmak amacıyla ilk olarak 2003 yılında hazırlanmış ve 2006 yılında Kılavuzun ikinci sürümü uygulamaya konulmuştur. Son olarak da yaşanan gelişim ve değişimler çerçevesinde, merkezine kamu idarelerini alarak 2018 yılında güncellenmiş ve üçüncü sürüm olarak yayımlanmıştır.

Mehmet Akif Ersoy Üniversitesi kalite çalışmalarına 5018 sayılı Kamu Mali Yönetimi ve Kontrol Kanunu çerçevesinde 2014 y1lında başlamış, Yüksekögrretim Kalite Güvencesi Yönetmeliği’ nin yürürlüğe girdiği 2015 y1lı itibariyle bu çalışmalar daha da önem kazanmıştır. Mehmet Akif Ersoy Üniversitesi mevcut yasa ve mevzuatlar çerçevesinde stratejik yönetim döngüsünü bütünüyle kapsayan “2017-2021 Dönemi Stratejik Planını” oluşturma çalışmalarına ise 2016 yılı itibariyle başlamış ve kalite uygulamalarının da gerçekleşebileceği 
bir ortam hazırlamıştır. Bu nedenle 2016 yılında oluşturulmasına başlanılan Stratejik Planda kalite, iç kontrol, kurumsal iç ve diş değerlendirme süreçlerine destek olacak hususlara yer verilmiştir. Stratejik Plan oluşturulurken öncelikle planın sahiplenilmesi sağlanmış, hazırlık ve sürecin organizasyonu için Stratejik Plan Yönlendirme Kurulu oluşturulmuştur. Daha sonra Stratejik Planlama Ekibi oluşturulmuştur. Stratejik Plan Yönlendirme Kurulu stratejik plan üzerinde genel değerlendirme yapmaktadır ve stratejik planlama ekibinin çalışmalarını değerlendirmektedir. Bu iki ekip oluşturulacak olan stratejik planın sınırlarını ve içeriğini oluşturmuşlardır.

Stratejik planın hazırlık faaliyetleri kapsamında sürecin aşamaları ve sürece ilişkin zaman çizelgesi belirlenmiş ve sürece ilişkin eğitim ihtiyacı tespit edilmiştir. Tüm bu tespitler üst yöneticinin onayına sunulmuş ve üst yönetici onayıyla süreç işlemeye başlamıştır.

Stratejik planlamanın ilk aşaması olarak durum analizi yapılmış ve "kurum olarak neredeyiz sorusuna" yanıt aranmaya çalışılmıştır. Bu aşamada kurumun tarihçesi, mevcut stratejik plan analizi, mevzuat analizi, PESTLE ve GZTF analizi, kurum içi analizi, paydaş vd. analizler yapılmıştır. Üniversite olarak kurum içi analiz ve paydaş analizlere dikkat edilmiştir. $\mathrm{Bu}$ iki çevre de stratejik planın sahiplenilmesi açısından hayati öneme sahiptir. Kurum içi analiz süreci sadece memnuniyet olarak görülmemiş ve iç paydaşların neredeyse tamamına yakını ile çeşitli toplantılar düzenlenerek görüş alışverişinde bulunulmuştur. Yine paydaş analizi sürecinde kurumun dış paydaşları belirlenmiş ve bu paydaşlar ile toplantılar düzenlenmiş ve paydaşların görüş ve önerileri de dikkate alınarak iç kontrol ve kalite uygulamalarının gereği yerine getirilmiştir. Her iki paydaş grubu ile yapılan bu etkinlikler stratejik planın benimsenme düzeyinin ve kalitesinin artırılmasını sağlamıştır.

Durum analizi aşamasında elde edilen sonuçlar kurumun tespitlerini ve ihtiyaçlarını oluşturmuştur. Böylece kurumun hedeflerini belirlemede en önemli yardımcı kaynak oluşturulmuştur. $\mathrm{Bu}$ veriler 1şı̆̆ında kurumun misyon, vizyon ve temel değerleri belirlenmiştir.

Paydaş toplantılarından elde edilen sonuçlar 1şı̆̆ında stratejik planlama ekibinin desteğiyle amaç ve hedefler ile performans göstergeleri belirlenmiştir. Daha sonra beyin fırtınası, mülakat, odak grup, kıyaslama vd. yöntemler kullanılarak stratejiler belirlenmiştir. Daha sonra hedefe ulaşma düzeyini gösterecek performans göstergeleri belirlenmiş ve bu göstergelere ulaşmayı ölçecek kontrol ve riske ilişkin faaliyetler tespit edilmiştir. Amaç ve hedeflere ulaşmada yürütülecek tüm bu faaliyetler maliyetlendirilmesi de yapılarak kurumun 
tüm kesimlerinin sahipleneceği; amaç, hedef ve göstergeleri somut olarak belirlenmiş olan stratejik plan oluşturulmuştur.

Mehmet Akif Ersoy Üniversitesi, 5018 sayıl Kamu Mali Yönetimi ve Kontrol Kanunu'nun 9. maddesine dayanılarak çıkarılan Performans Programları Hakkında Yönetmelik ile Performans Programı Hazırlama Rehberine uygun olarak Performans Programı hazırlamaktadır. Bu kapsamda kurum bütçesi stratejik planda yer alan misyon, vizyon, amaç ve hedefleri gözetilerek ve performans esası dikkate alınarak hazırlanmıştır. Hazırlanmış olan stratejik plan ile bütçeyi ilişkilendirmek ve bir köprü görevi görmesi amacıyla da performans programı düzenlenmektedir. Genel bütçe kapsamındaki idareler ile özel bütçeli idarelerin performans programları kurum üst yöneticisi tarafından nihai hali verilerek kamuoyuna açıklanmakta ve Bakanlığa ve Devlet Planlama Müsteşarlığına gönderilmektedir.

Kurumumuz performans programı idare düzeyinde hazırlanmıştır. Hazırlık sürecine üst yönetici ve harcama yetkililerinin katılımı ile hedefler ve bu hedeflere ulaşmada kullanılan göstergelerden sorumlu harcama birimlerinin tespiti ile başlanmıştır. Stratejik plan ile de belirlenmiş olan sorumlu birimler tarafından faaliyetlerin maliyetleri belirlenmiş ve kurum mali hizmetler birimine bildirilmiştir. $\mathrm{Bu}$ veriler üst yöneticinin katılımı ile konsolide edilmekte ve kurumun öncelikleri, hedefleri, maliyet ve kaynak ihtiyaçları belirlenmektedir.

Performans Programı stratejik plan ile belirlenen amaç ve hedeflere 1şık tutmakta ve bu hedeflerin yıllık dilimler halinde gerçekleşme performanslarını görmeyi sağlamaktadır. Böylece kamu kurumu için daha etkin bir yönetim, saydamlık ve hesap verilebilirlik gerçekleştirilmektedir. Ayrıca bu hedefler ile bütçe arasında bağlantı kurularak idarenin kaynakların tahsisinde ve kullanımında etkinliği sağlanmaktadır. Yine bu işlevleri nedeniyle performans programı kalite uygulamalarında izleme ve denetim işlevini de yerine getirmektedir.

Kamu kurumları orta ve uzun vadeli hedeflerine ulaşma sürecinde, kurumsal kapasitesini ve kabiliyetini, hedeflerinde meydana gelebilecek değişiklikleri ve karşılaşabileceği riskler ile bu risklere karşı alacağı önlemleri değerlendirebilmek amacıyla faaliyet raporu hazırlamaktadır. Faaliyet raporu hazırlanırken dikkat edilmesi gereken ilkeler:

Y1llı olma ve sorumluluk ilkesi,

Açıklık, doğruluk ve tarafsızlık ilkesi, 
Açıklama ve tutarlılık ilkesidir.

5018 sayılı Kamu Mali Yönetimi ve Kontrol Kanunu gereği kamu kuruluşları faaliyet raporlarında sunacakları verilerin kalitesinden sorumludur. Genel bütçe kapsamındaki idareler ile özel bütçeli idarelerin performans programları kurum üst yöneticisi tarafından nihai hali verilmekte ve kamuoyuna açıklanarak Bakanlığa ve Sayıştay’a gönderilmektedir. Bu kapsamda Mehmet Akif Ersoy Üniversitesi faaliyet raporunu her yıl düzenli olarak hazırlamakta ve ilgililerine göndermektedir. $\mathrm{Bu}$ raporda, stratejik plan ile belirlenen faaliyetler ve bu faaliyetlere ilişkin göstergeler değerlendirilmekte, yeni yılın planlaması yapılmaktadır. Bu rapordan elde edilen veriler diğer kalite süreçlerine de katkı sağlamaktadır. Faaliyet raporu hazırlanırken genel bilgiler alanında, kurumun misyon ve vizyonuna, sunulan hizmetlere, görev ve sorumluluklara ve idareye ilişkin bilgilere yer verilmiştir. Amaç ve hedefler alanında kurum amaç ve hedeflerine, temel politika ve önceliklere yer verilmiştir. Faaliyetlere ilişkin bilgiler alanında mali bilgilere ve faaliyet ve projeler ile ilgili bilgilere yer verilmiştir. GZTF analizi yapılarak kurumsal kabiliyet ve kapasite değerlendirilmiştir. Tüm bu bilgi ve değerlendirmeler 1şığında da öneri ve tedbirler öne sürülmüştür.

\section{4. İÇ KONTROL EYLEM PLANI}

Kamu kurumlarında iç kontrol sisteminin oluşturulması ya da mevcut iç kontrol uygulamalarının Kamu İç Kontrol Standartları ile uyumlu hale getirilmesi amacı ile Kamu Iç Kontrol Standartlarına Uyum Eylem Planı Rehberi yayımlanmıştır. Kamu kurumları iç kontrol sistemini oluştururken veya uyumlu hale getirirken bu rehber yardımı ile gerekli prosedürleri ve diğer düzenlemeler için bir eylem planı oluşturmalıdır. $\mathrm{Bu}$ rehber ile kurumlardan beklenen davranış, iç kontrol sitemini oluşturan beş standardı sağlayabileceği bir takvim oluşturması ve bunu kamuoyu ile paylaşmasıdır.

Kamu Kurumlarınca hazırlanacak bir İç Kontrol Eylem Planı azami aşağıdaki bilgileri içermelidir:

İç kontrol standardı bileşeni, kod numarası ve genel şartını,

Mevcut durum analizini,

Eylem kod numarasını,

> Yapılması planlanan eylem veya eylemler ile eylemlerden sorumlu birimlerden oluşturulacak çalışma gruplarını

> İşbirliği yapacak birimler veya çalışma gruplarını 
Dylemin gerçekleştirilmesinden elde edilecek standart, rapor, çizelge, rehber el kitabı vb. çıktıları veya sonuçları,

$>$ Eylem için planlanan tamamlanma tarihini ve

Açıklamalar.

Mehmet Akif Ersoy Üniversitesi yayınlanan bu rehber yardımı ile ve kurum yönetiminin sorumluluğunda öncelikle iç kontrol sistemini oluşturmak ve bu sistemin işleyişini sağlamak amaciyla yönetim modelini ve yöntemini belirlemiş, iç kontrol standartlarına uyum eylem planını oluşturmuş ve kalite standartlarını sağlayacak genel şartlar ile bu şartları hangi tarihte sağlamaya başlayabileceğini taahhüt etmiştir. Eylem planın hazırlanmasına üst yöneticinin liderliğinde ve onayıyla, strateji biriminin desteğiyle ve harcama birimlerinin katılımıyla başlanmıştır. Gerekli hallerde iç denetim biriminden de destek alınmıştır. Çalışmanın amacı, kapsamı, birimler, oluşturulacak kurullar ile bu kurullarda görev alacak personele ilişkin veriler, sürecin izlenmesine ilişkin süreçler belirlenmiştir. Hazırlanan eylem planına kurumun tüm birimlerinin mali ve mali olmayan süreçleri ile eylem ve kararları da dahil edilmiştir. Eylem planında yer alan tüm düzenlemeler yanlış anlaşılmaya mahal vermeyecek açıklıkta anlatılmıştır. Planının "mevcut durum" alanında, tüm düzenleme veya uygulamaların makul güvence sağladığı, "açıklama" bölümünde de bu nedenle yeni bir düzenleme veya uygulamaya gerek bulunmadığı hususuna yer verilmiştir. Hazırlanan rapor değerlendirilmek ve varsa düzenleme yapılması amacıyla üst yöneticinin onayına sunulmuştur. Son hale getirilen ve üst yöneticinin onayından geçen iç kontrol eylem planı kamuoyu ile de paylaşılmıştır.

\section{KURUM İÇ DEĞERLENDİRME RAPORU}

Üniversiteler, kurumlarında uygulayacağı iç ve dış kalite güvence sisteminin ve uygulamalarının oluşturulmasından ve sürdürülmesinden sorumludur. $\mathrm{Bu}$ sorumluluğunu yerine getirdiğinin göstergesi olarak hazırlanan raporlardan birisi de Kurum İç Değerlendirme Raporudur. Kurum İç Değerlendirme raporu üniversitelerin eğitim-öğretim ve araştırma faaliyetleri ile idari faaliyetleri de kapsamakta; kurum stratejik planı, faaliyet raporu ve performans programı ile bir bütün olarak değerlendirilmekte ve hazırlanmaktadır.

Kurum iç değerlendirme raporu, kurumun yıllık iç değerlendirme süreçlerini izlemek, iç kontrol sisteminin izleme ve değerlendirme standartlarını karşılamak ve en az bir defa gerçekleştirilecek olan diş denetim sürecinde de esas alınmak amacıyla kurum tarafından düzenli dönemler halinde hazırlanmalıdır. 
Kurum İç Değerlendirme Raporu, Kalite Güvencesi, Eğitim-Öğretim, Araştırma Geliştirme ve Yönetim Sistemi olmak üzere dört ana temayı içerecek şekilde hazırlanmalıdır. Bölgesel Kalkınma Odaklı Misyon Farklılaşması ve İhtisaslaşması Programını yürüten üniversiteler bu dört ana temaya ek olarak bu program kapsamındaki faaliyetlerini de beşinci tema olacak şekilde eklemelidir. Kurumun ilk yıl sunduğu Kurum İç Değerlendirme Raporunda yer verdiği bu temalar ile ilgili bilgilere ikinci yılda yer vermesine gerek yoktur. Sadece değişen ve geliştirilen yönler ile başarı sağlanamayan noktalara ilişkin hususları nedenleriyle birlikte açıklaması yeterlidir.

Kurum iç değerlendirme raporu, Yükseköğretim Kalite Kurulu tarafindan kurumun nitelik ve nicelik yönünden değerlendirilebilmesi için gerekli verilerin sağlanması amacıyla, yasa ve mevzuatında belirlenen standartları sağlamalı ve tüm bilgi ve belgeleri içermelidir. $\mathrm{Bu}$ kapsamda kurumlar, Kurum İç Değerlendirme Raporunu hazırlarken asgari aşağıdaki sorulara cevap verebilmelidir:

> "Kurum ne yapmaya çalışıyor?" sorusuna cevap olarak kuruluşun misyon, vizyon ve hedefleri belirtilmelidir,

$>$ "Kurum misyon ve hedeflerine nasıl ulaşmaya çalışıyor?" sorusuna cevap olarak kuruluşun yönetişim ve organizasyon yapısı, yönetsel süreçler ve faaliyetleri hakkında bilgi verilmelidir,

$>$ "Kurum misyon ve hedeflerine ulaştı̆ğna nasıl emin oluyor?" sorusuna cevap olarak kuruluşun kalite ve iç değerlendirme süreçleri hakkında bilgi verilmelidir,

$>$ “Kurum geleceğe yönelik süreçlerini nasıl iyileştirmeyi planlıyor?” sorusuna cevap olarak, kuruluşun rekabet avantajı yaratabilmek veya rekabet gücünü koruyabilmek için yapabileceği faaliyetler hakkında bilgi verilmelidir.

Mehmet Akif Ersoy Üniversitesi, Yükseköğretim Kalite Güvencesi Yönetmeliği’nde belirtilen esaslar çerçevesinde hazırlamış olduğu Mehmet Akif Ersoy Üniversitesi Kalite Güvencesi Yönetmeliği'nce iç ve dış değerlendirme ile kalite geliştirme çalışmalarının yürütülmesi için Kalite Komisyonu ve Kalite Alt Komisyonlarını oluşturmuştur. Kalite Komisyonunda üst yönetimden yöneticilerin yer almasına dikkat edilmiştir. Kalite Alt Komisyonlarında da yönetmelik ile belirtilen temalara yönelik uzman personel görevlendirilmiştir. Kurum, Kalite Komisyonunun koordinatörlüğünde Kalite Alt Komisyonlarınca Kurum İç Değerlendirme Raporu hazırlama çalışmalarına başlamakta ve yürütmektedir. Kalite alt komisyonları, raporun hazırlanma safhasında ilgili birimlerden 
destek almaktadır. Bu çerçevede hazırlanan Kurum İç Değerlendirme Raporu değerlendirilerek üst yönetici onayına sunulmaktadır. Üst yönetici onayı ile kesinleşen rapor Yükseköğretim Kalite Kuruluna bildirilmekte ve Kurum internet adresi üzerinden tüm paydaşlarına da ilan edilmektedir.

\section{KURUM DIŞ DEĞERLENDIRME RAPORU}

Yükseköğretim Kalite Güvencesi Yönetmeliği’nde diş değerlendirme, "Bir yükseköğretim kurumunun veya programının, eğitim-öğretim ve araştırma faaliyetleri ile idarî hizmetlerinin kalitesinin, Yükseköğretim Kalite Kurulu tarafından yetkilendirilen diş değerlendiriciler veya Yükseköğretim Kurulunca tanınan, bağımsız Kalite Değerlendirme Tescil Belgesine sahip dış değerlendirme kuruluşları tarafından yürütülen dış değerlendirme süreci” olarak tanımlanmıştır. Bu kapsamda Yükseköğretim Kalite Kurulu tarafından değerlendirme esasları, Avrupa Standartlar Rehberi (ESG), Avrupa Üniversiteler Birliği Kurumsal Değerlendirme Programı Rehberi (EUA-IEP) ve Kurumsal Dış Değerlendirme Yönergesi dikkate alınarak belirlenmiştir.

Tüm bu veriler 1şı̆̆ında dış değerlendirme, uluslararası kabul görmüş standartlar çerçevesinde ulusal değerlendirme; kuruluşun misyon, vizyon ve hedeflerine ulaşma düzeyini ölçmeye çalışan; kuruma öz değerlendirme yapma firsatı sağlayan; kurumun iç ve dış paydaşlarının görüşlerini, akran değerlendirmesi yöntemiyle değerlendirilmesini sağlayan; kurumun GZTF analizi yapmasını ve PUKO döngüsü ile değerlendirme firsatı sağlayan süreçler bütünüdür. Kurumsal dış değerlendirme sürecinin başlayabilmesi için kurumun dış değerlendirme talebinde bulunması gerekir. Bu talebi Yükseköğretim Kalite Kuruluna Kurum İç Değerlendirme Raporu ile yapar. Yükseköğretim Kalite Kurulu tarafından Kurum Dış Değerlendirme Komisyonu oluşturulur ve bu komisyon kurumlardan gelen Kurum İç Değerlendirme raporlarını inceleyerek, ilgili yılda dış değerlendirme takvimine alınacak kurumları belirler. Komisyon takvime dahil edilen kurumlara bilgi verir. Daha sonra değerlendirici listesi ve değerlendirme takımları belirlenerek yükseköğretim kurumları ile eşleştirilir. Eşleştirmesi yapılan değerlendirme takımları ilgili kurumlar ile iletişime geçerler. Kurumsal diş değerlendirme süreci, ziyaret öncesi etkinlikler, kurum ziyareti ve ziyaret sonrası etkinlikler olmak üzere üç evreden oluşmaktadır. Ziyaret öncesi etkinlikler ilgili yılın Temmuz-Ekim ayları arasında yapılmaktadır. Bu evrede değerlendirme takımı, kurumun iç değerlendirme raporu üzerinden değerlendirme yapar ve saha ziyareti programını hazırlar. Kurum ziyareti evresi Ekim-Kasım aylarında gerçekleştirilir. Bu evrede değerlendirme takımı, 
üç günlük takvim çerçevesinde saha ziyaretlerini gerçekleştirir. Ziyaret sonrası etkinlikler evresi ise Kasım-Aralık aylarında gerçekleştirilen faaliyetlerdir. $\mathrm{Bu}$ evrede değerlendirme takımı, Kurumsal Geri Bildirim Raporunu hazırlar ve ilgili kurum ile paylaşır. Bu raporun kuruma bildirilmesinden 30 gün sonra nihai Kurumsal Geri Bildirim Raporu oluşturulmaktadır.

Kurumsal dış değerlendirme sürecinde karşılıklı bir değerlendirme söz konusudur. Yani değerlendirme takımı kurumu ve faaliyetlerini değerlendirirken kurumda değerlendirme takımını ve değerlendirme sürecini değerlendirmektedir. Kurum bu değerlendirmesini Yükseköğretim Kalite Kuruluna iletir. Böylece sürecin ve değerlendirme takımının iyileştirilmesi fırsatı yaratılmış olur.

\section{SONUÇLAR}

Sonuç olarak ülkemizde üniversitelerde iç kontrol ve kalite standartlarının oluşturulması ve yerleştirilmesi; izleme ve değerlendirme süreçlerinin geliştirilmesi ve standardizasyonu konusunda son yıllarda hem yasal mevzuat yönünden hem de uygulama örnekleri yönünden hızlı gelişmeler yaşanmaktadır. Yönetsel faaliyetlere yadsınamayacak bir destek sağlayan bu standart ve raporlar, kurum kültürünün oluşmasına ve korunmasına da katkı sunmaktadır. İç Kontrol sisteminin oluşturulması ve uygulamalarında kurum üst yöneticileri süreçlere dahil edilmiştir. Uygulama sonuçları incelendiğinde iç kontrol sistemi ve uygulamalarının sahiplenilmesi, yetkilendirme ve izleme çalışmalarının sürdürülmesi çalışmalarında üst yöneticilerin desteği ve katılımı büyük önem arz etmektedir. Süreçlerin uygulama ve iyileştirilmesi çalışmalarında üst yöneticiler büyük katkı sağlamaktadır.

Kamu kurumları yayınlanan rehberlerden faydalanarak yönergeler hazırlamakta ve belirleyeceği ilke ve yöntemler için dayanak oluşturmaktadır. Bu sayede kuruma özgü süreçler hazırlanabilmektedir.

Üniversiteler hem yasal zorunluluğun gereği olarak, hem de gelişim ve değişime ayak uydurarak kurumsal performans yönetimini gerçekleştirmek için belirlenen bu standartları uygulamaya koymaya çalışmaktadır. Yönetmeliklerde ve rehberlerde kamuoyunun bilgilendirilmesine yönelik maddeler bulunmakta ve kurumlar bu sayede teşvik edilmektedir. Yine kurumlar bu uygulamalar sayesinde şeffaflık ve hesap verilebilirliği güçlendirmekte, kamuoyunu bilgilendirmede de bir standart oluşturmaktadır. Oluşturulan standartlar sayesinde kurum paydaşları sunulan bilgilere kolaylıkla erişebilmektedir. Kamuoyuna ilan edilen 
raporlar dış denetim süreçlerine katkı sağlamakta ve dış denetimler için standart bilgi oluşturmaktadır.

Sonuç olarak Üniversite, İç Kontrol ve Kalite uygulamalarını arttırdıkça ve geliştirdikçe gelişim ve değişime açık olacak, şeffaflığını ve hesap verebilirliğini güçlendirecek, kurumsal yönetim uygulamalarının gelişimine katkıda bulunacaktır.

\section{REFERENCES / KAYNAKLAR}

Arslan, A. (2012). Kamu İdarelerinde Stratejik Planlama-Performans Programı-Faaliyet Raporlaması-İç Kontrol Sistemi, Seçkin Yayıncılık, Ankara, 128-129.

İç Kontrol ve Ön Mali Kontrole İlişkin Usul ve Esaslar, RG Tarihi: 31.12.2005, RG Sayısı: 26040, Erişim Tarihi:26.03.2018,http://www.mevzuat.gov.tr/Metin.Aspx?MevzuatKod=7.5.9813\&Mevzuatlliski=0\&sourceXm 1Search=\%C4\%B0\%C3\%A7\%20Kontrol\%20ve\%20\%C3\%96n\%20Mali\%20Kontrole\%20\%C4\%B0li\%C5\%9F kin\%20Usul\%20ve\%20Esaslar

Kamu İç Kontrol Standartları Tebliği, RG Tarihi: 26.12.2007, RG Sayısı: 26738, Erişim Tarihi: 26.03.2018, http://www.resmigazete.gov.tr/eskiler/2007/12/20071226-21.htm

Kamu İç Kontrol Rehberi, T.C. Maliye Bakanlı̆̆ı, Bütçe ve Mali Kontrol Genel Müdürlüğü, Ver: 1., Erişim Tarihi: 26.03.2018, http://www.bumko.gov.tr/TR,5559/kamu-ic-kontrol-rehberi-yayimlanmistir.html

Kamu İç Kontrol Standartlarına Uyum Eylem Planı Rehberi, Erişim Tarihi: 26.03.2018, http://kontrol.bumko.gov.tr/TR,2260/kamu-ic-kontrol-standartlarina-uyum-eylem-plani-rehberi.html

Kamu İdareleri İçin Stratejik Planlama Kılavuzu, 2. Sürüm, DPT (2006). RG Tarihi: 26.05.2006, www.sp.gov.tr.

Strateji Geliştirme Birimlerinin Çalışma Usul ve Esasları Hakkında Yönetmelik, Yayımlandığı R.G Tarihi:

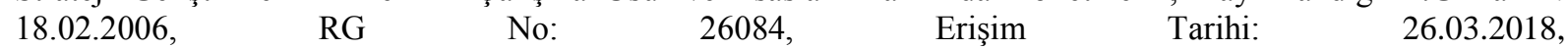
http://www.mevzuat.gov.tr/Metin.Aspx?MevzuatKod=3.5.20069972\&sourceXmlSearch=\&MevzuatIliski=0

124 sayılı Yükseköğretim Üst Kuruluşları İle Yükseköğretim Kurumlarının İdari Teşkilatı Hakkında Kanun Hükmünde Kararname, RG: 21.11.1983, RG No: 18228, Erişim Tarihi: 26.03.2018, http://www.mevzuat.gov.tr/Metin1.Aspx?MevzuatKod=4.5.124\&Mevzuatlliski=0\&sourceXmlSearch=\&Tur=4 $\&$ Tertip $=5 \& \mathrm{No}=124$

2547 sayılı Yükseköğretim Kanunu, RG Tarihi: 06.11.1981, RG Sayı: 17506, Erişim Tarihi: 26.03.2018, http://www.mevzuat.gov.tr/Metin1.Aspx?MevzuatKod=1.5.2547\&MevzuatIliski=0\&sourceXmlSearch=\&Tur=1 $\&$ Tertip $=5 \& \mathrm{No}=2547$

5018 sayılı Kamu Mali Yönetimi ve Kontrol Kanunu, RG Tarihi: 24.12.2003, RG Sayısı: 25326, Erişim Tarihi: 26.03.2018,http://www.mevzuat.gov.tr/Metin1.Aspx?MevzuatKod=1.5.5018\&MevzuatIliski=0\&sourceXmlSear ch\&Tur $=1 \&$ Tertip $=5 \& \mathrm{No}=5018$

Üniversiteler İçin Stratejik Plan Hazırlama Rehberi, (2016). Erişim Tarihi: 26.03.2018, http://sgdb.gazi.edu.tr/posts/view/title/universiteler-icin-stratejik-planlama-rehberi-yayinlanmistir-184579

Yükseköğretim Kalite Güvencesi Yönetmeliği, RG Tarihi: 23.07.2015, RG Sayı: 29423, Erişim Tarihi: 26.03.2018, http://www.resmigazete.gov.tr/eskiler/2015/07/20150723-3.htm 
Yükseköğretim Kalite Kurulu, Yükseköğretim Kalite Kurulu Kurumsal Diş Değerlendirme Yönergesi, 11.05.2016, Erişim Tarihi: 26.03.2018, http://kalite.sdu.edu.tr/dosya-detay/82-yuksekogretim-kalite-kurulukurumsal-dis-degerlendirme-yonergesi.html 